\title{
Targeted therapy aimed at cancer stem cells: Wilms' tumor as an example
}

\author{
Rachel Shukrun • Naomi Pode Shakked • Benjamin Dekel
}

Received: 4 March 2013 /Revised: 10 April 2013 /Accepted: 29 April 2013 /Published online: 13 June 2013

(C) IPNA 2013

\begin{abstract}
Wilms' tumor (WT), a common renal pediatric solid tumor, serves as a model for a malignancy formed by renal precursor cells that have failed to differentiate properly. Here we review recent evidence showing that the tumors' heterogeneous cell population contains a small fraction of cancer stem cells (CSC) identified by two markers: Neural Cell Adhesion Molecule 1 (NCAM1) expression and Aldehyde dehydrogenase 1 (ALDH1) enzymatic activity. In vivo studies show these CSCs to both self-renew and differentiate to give rise to all tumor components. Similar to other malignancies, the identification of a specific CSC fraction has allowed the examination of a novel targeted therapy, aimed at eradicating the CSC population. The loss of CSCs abolishes the tumor's ability to sustain and propagate, hence, causing tumor degradation with minimal damage to normal tissue.
\end{abstract}

Keywords Wilms' tumor · Cancer stem cells $\cdot$ Kidney stem cells $\cdot$ Renal progenitor cells $\cdot$ Targeted therapy

Rachel Shukrun and Naomi Pode Shakked contributed equally to this review.

R. Shukrun • N. Pode Shakked • B. Dekel $(\bowtie)$

Pediatric Stem Cell Research Institute, Edmond and Lily Safra

Children's Hospital, Sheba Medical Center, Ramat-Gan, Tel

Hashomer 52621, Israel

e-mail: benjamin.dekel@gmail.com

R. Shukrun $\cdot$ N. Pode Shakked $\cdot$ B. Dekel

Sheba Centers for Regenerative Medicine and Cancer Research, Sheba Medical Center, Ramat-Gan, Israel

R. Shukrun $\cdot$ N. Pode Shakked $\cdot$ B. Dekel

Sackler School of Medicine, Tel Aviv University, Tel Aviv, Israel

B. Dekel

Division of Pediatric Nephrology, Edmond and Lily Safra

Children's Hospital, Sheba Medical Center, Ramat-Gan, Israel

\section{Introduction}

Wilms' tumor (WT), also known as nephroblastoma, is the most common pediatric renal tumor. It accounts for $6 \%$ of tumors in patients under the age of 15 and is the second most frequent intra-abdominal pediatric tumor [1]. WT affects 1 in 10,000 children in North America, usually arising before the age of 5 with equal incidence between genders [2]. Most WT cases are sporadic, although 1-2\% of patients have a family history. Familial cases are associated with a higher frequency of bilateral tumors, as well as a lower age at diagnosis [2]. Genetic alterations are observed in only one-third of all Wilms' tumors, while the most common changes occur in the WT1, WTX, CTNNB1 (encodes $\beta$ catenin), and TP53 genes. Several syndromes are associated with an increased incidence of Wilms' tumor; these include WAGR (Wilms' tumor, aniridia, genitourinary abnormalities, and mental retardation), Denys-Drash syndrome, Frasier syndrome, and Beckwith-Wiedemann syndrome among others [3]. The fact that two-thirds of all WT cases cannot be linked to any genetic aberration emphasizes the need to further explore the pathophysiology of these tumors. WT is characterized by its unique histology; the tumor is composed of three main elements: blastema, epithelia, and stroma. The blastema component consists of sheets of densely packed small cells with hyperchromatic nuclei and conspicuous mitotic activity; the epithelial component consists of primitive cuboidal cells forming tubular structures and rosettes; and the stromal component is composed mainly of fibroblast-like cells that reside between nodules of blastema. This unique histology is suggestive of incomplete and disorganized kidney development. Accordingly, the tumor is believed to arise from renal precursor cells which have failed to differentiate properly. The differentiation failure results in the appearance of similar tissue components in WT as in the fetal kidney (i.e., blastema, stroma, and epithelia) without proper tissue architecture (Fig. 1). Thus, WT 


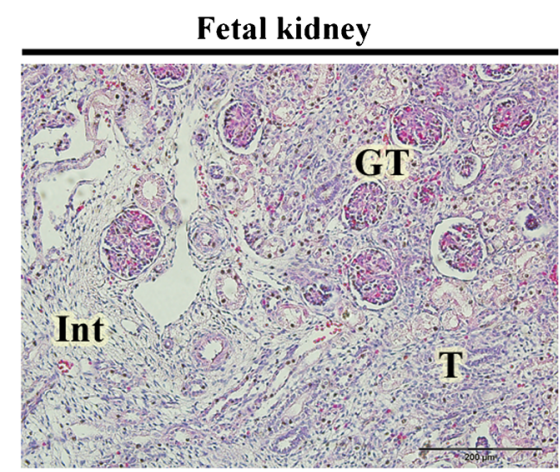

Fig. 1 Wilms' tumor and the human fetal kidney show marked histological resemblance. H\&E staining of favorable histology tri-phasic WT (right) and human fetal kidney (left) showing similar cellular components in both tissues - Blastema (B) vs. the metanephric mesenchyme (MM;

is an attractive model for studying the connection between cancer and development. In fact, WT research has already provided significant information regarding the genetic and epigenetic events leading to the development of pediatric tumors. Specifically, global gene and chromatin analysis comparing WT to the renal progenitor pool of the developing human kidney has linked early renal stem/progenitor genes to WT oncogenesis [4-10].

\section{Cancer stem cells_-past and current}

Similar to the tissues from which they arise, neoplasms have long been viewed as being composed of heterogeneous populations of cells [11]. While most cells are destined to differentiate, albeit aberrantly, and eventually stop dividing, a small subset of cells within the tumor, termed cancer stem cells (CSCs), actively sustain the capability of the tumor to grow and propagate. The cancer stem cell population is defined by two main properties which they share with their normal counterparts: self-renewal and differentiation capacities (Fig. 2). Self-renewal is a unique property, allowing unlimited cell division and preservation of the stem cell pool in the tissue. The ability of stem cells to differentiate and create progeny that continue to divide until they produce terminally differentiated specialized cells, allows them to regenerate the tissue in which they reside. Both these properties apply also to CSCs, allowing them to initiate tumors and maintain their growth, while giving rise to all cell phenotypes of the parental tumor. Other key features of both normal and cancer stem cells include: activation of pluripotency genes (i.e., OCT4, SOX2,NANOG), formation of tumor spheres in low-adherence cultures, and multi-drug resistance [12]. Cancer stem cells are thought to differ from their normal counterparts in their ability to continuously proliferate and sustain tumor growth, disregarding inhibitory signals from their environment [13]. This independence

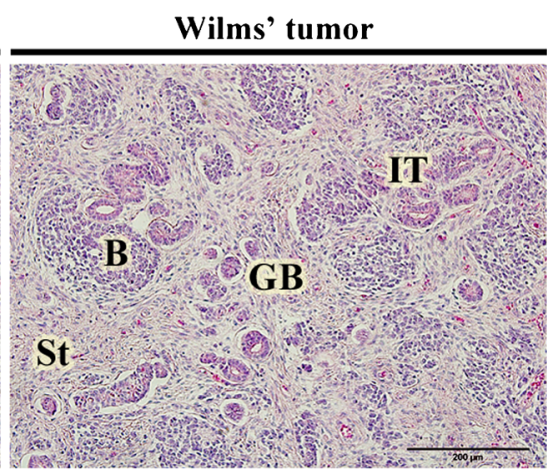

not shown); immature tubules (IT) vs. tubules (T); glomeruloid bodies (GB) vs. glomerular tuft (GT) and stroma (St) vs. interstitium (Ins) - in WT and the human fetal kidney, respectively

can be explained by the differences between normal stem cells and cancer stem cells in the degree to which they depend on the stem cell niche, a specific microenvironment in which stem cells reside. It has been shown that the stem cell niche in normal adult tissues plays an essential role in maintaining stem cells as well as preventing tumorigenesis by providing inhibitory signals for proliferation and differentiation. On the other hand, it provides stimulatory signals for stem cell proliferation when tissue regeneration is needed [14]. The balance between inhibitory and stimulatory signals is the key for regulation of the balance between stem cell maintenance and tissue regeneration [15].

The history of the CSC theory can be traced back more than 70 years. In 1941, teratocarcinomas were found to contain both differentiated and undifferentiated cells, leading to the notion that the undifferentiated cells represent multi-potent cancer cells [16]. In 1963, over four decades ago, Bruce and Van Der Gaag were the first to suggest the

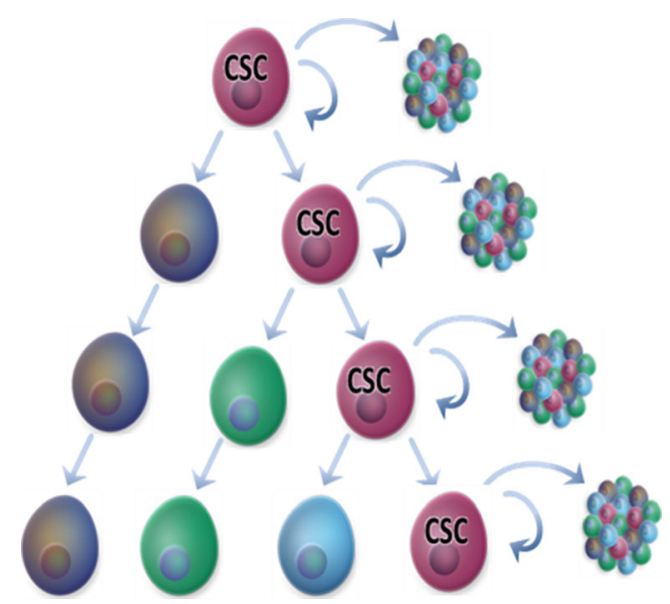

Fig. 2 The cancer stem cell model. A cancer stem cell (red) is defined by two main properties: self-renewal and differentiation capacities. A single cancer stem cell (CSC) possesses the ability to form a full heterogeneous tumor, recapitulating all cell types found in the original tumor 
existence of cancer initiating cells (CICs) in murine lymphoma and a method for their in vivo quantification [17]. In 1977, Hamburger et al. published a method for supporting colony growth of human tumor stem cells in soft agar [18, 19]. Buick et al. developed an in vitro system for measuring the frequency of clonogenic cells within tumors more accurately in semi-solid cultures $[20,21]$. They managed to demonstrate the self-renewing ability of blast progenitors in acute myeloid leukemia (AML) [22, 23]. Consequently, McCulloch and colleagues postulated that AML can be considered as a clonal hemopathy $[22,23]$. However, the first prospective identification, characterization, and isolation of CSC/CICs was performed years later in AML on the basis of their phenotypical similarities to normal hematopoietic stem cells [24]; in their innovative work, Dick and colleagues have identified $\mathrm{CD} 34^{+} \mathrm{CD} 38^{-}$cells as $\mathrm{AML}$ CSCs $[24,25]$. Subsequently, the group reported that only $\mathrm{CD} 34^{+} \mathrm{CD} 38^{-}$cells were able to reproduce AML in recipient immunodeficient mice, which closely resembled the original patient's disease, and exhibited its full heterogeneous phenotype.

Following AML, recent years have seen the identification and isolation of cancer stem cells in various solid organ malignancies. The first to identify such cells was Al-Hajj who found that breast cancer cells with CD24-CD44+ phenotype are able to form tumors that recapitulate their parental tumor when implanted in the mammary fat pad [26]. Immediately following this discovery, CD133+ cells were identified as tumor stem cells in glioblastoma brain tumors [27] and thereafter in colon cancer [28]. In the past few years, high ALDH1 activity levels have been used to identify CSCs in a variety of tumors including liver, head and neck, colorectal, breast, multiple myeloma, acute myeloid leukemia, and brain cancers [29-35]. Moreover, a link between poor prognosis and increased ALDH1 activity was found in breast tumors [33]. Since the above discoveries, as well as additional CSCs markers, CSCs have been prospectively isolated from a variety of malignancies, thus far including pancreas, skin, head and neck, and prostate cancers, and the list is ever growing [26-28, 36-38]. The identification of CSCs was facilitated by significant progress achieved over the last several years in this field. To date, the gold standard for CSC identification is xenotransplantation of human tumor cells into immunodeficient mice. The injection of tumor cell subpopulations, selected based on the differential expression of specific markers, allows the assessment of the tumorigenic potential of different subpopulations within the tumor. The subpopulation identified with tumorigenic capacity is implicated as the CSC population. In addition, mainly for support of the in vivo methods, in vitro assays have been developed for CSC identification, including colony formation assay, sphere formation assay, the side population (SP) assay, differentiation potential assays, and label retention cell assay [39].

Despite significant improvements in cancer treatment in the past few decades, two of the major challenges remaining are late cancer relapse and tumor resistance to therapy. These challenges may result from residual cancer stem cells, which may be resistant to conventional chemo- and radiotherapies and are therefore difficult to eradicate. Gerber et al. demonstrated, for the first time, that the presence of CSCs in AML correlates with a poor clinical outcome and suggested that those cells may be responsible for tumor relapse [40]. Therefore, these cells could be responsible for the selection of drug-resistant clones and the eventual development of multidrug resistance (Fig. 3). There are several mechanisms that may mediate CSC resistance to chemotherapy and radiation, these include: the quiescent nature of CSCs shown in several malignancies, their presence in hypoxic niches into which therapies fail to penetrate, the up-regulation of DNA damage response mechanisms by these cells, and their increased drug efflux capacity [41].

Fig. 3 CSCs are resistant to conventional chemo-/ radiotherapies. Conventional therapy (top) does not target the CSC fraction. Despite tumor size reduction, the tumor initiation capacity is maintained and the tumor relapses. Only a treatment strategy that specifically targets CSCs (bottom) may lead to a complete and durable regression of malignant cancers
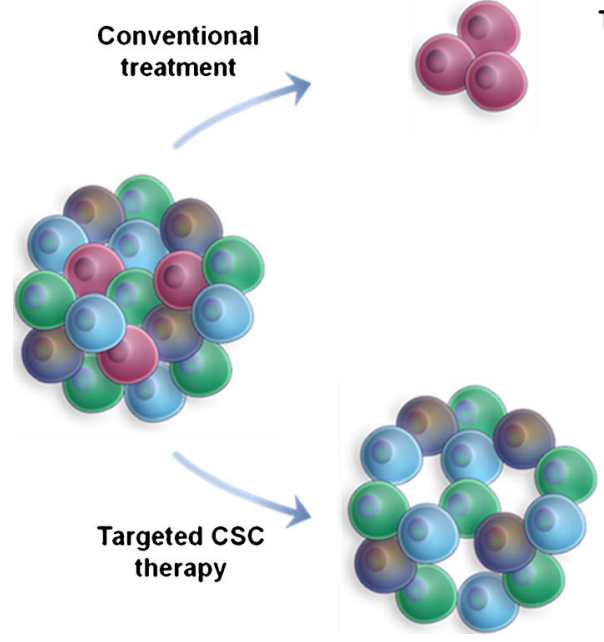

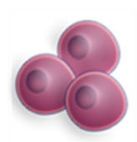

Tumor relapse
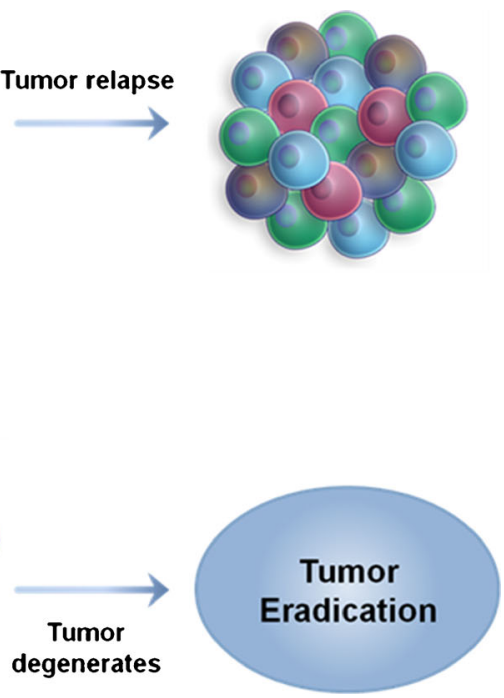
Identifying the CSCs and understanding the mechanisms involved may assist unraveling new therapeutic targets and creating new improved specific treatments (Fig. 3).

\section{Cancer stem cells in Wilms' tumors}

Following the definition of what a cancer stem cell is (see previous section), our lab attempted to study the CSC model in WT. Studying the CSC model in WT employs the use of single tumorigenic WT cells upon xeno-transplantation. This presented two main inherent limitations: first, tumorigenicfavorable histology WT cell lines are not obtainable, and second, primary Wilms' tumor tissues, like other pediatric solid tumors, are less available compared to fresh surgical adult carcinomas [42]. Moreover, establishment of WT xenografts from single cells, derived from fresh primary WT, has been estimated at $30 \%$ graft take [43] and in our experience approximately $10 \%$, while after culture and in vitro growth of primary WT cells, xenograft formation is unattainable. These limitations were circumvented by the establishment of human WT xenograft models that recapitulated the components of the original parental tumor. Single tumorigenic WT cells could be robustly derived from these human WT xenografts and afforded the opportunity to perform in vitro and in vivo assays required to examine the CSC model in WT. Previous work aimed at deciphering the clonogenic and progenitor properties of primary WT cells in vitro suggested NCAM1 as a putative marker for WT CSCs [44]. The NCAM1+ cell population was shown to be highly clonogenic, over-expressing WT stemness and progenitor genes (e.g., WT1, SIX2, EZH2, BMI-1, FZD7, $N A N O G$ ) and topoisomerase 2A (TOP2A), a WT bad prognostic marker. Later, by working with the WT xenograft model, performing limiting xenotransplantation (LDTA), we were able to show that the initiation and propagation of human WT xenografts by unsorted WT-xenograft-derived cells required a minimum of 10,000 cells. Hence, the propagation of human WT in mice self-enriches for the CSC phenotype [6, 42]. However, only prospective isolation of the $\mathrm{NCAM}^{+}{ }^{+} \mathrm{WT}$ cell fraction from xenografts enabled tumor initiation and propagation from as few as 500 cells. Further fractionation of the $\mathrm{NCAM}^{+}$heterogeneous population into cell subsets revealed that the addition of aldehyde dehydrogenase 1 (ALDH1) activity to NCAM1 expression during cell selection, allowed for tumor initiation from only 200 purified $\mathrm{NCAM}^{+}{ }^{+} \mathrm{ALDH}^{+}{ }^{+}$cells. Xenografts derived from the $\mathrm{NCAM}^{+} \mathrm{ALDH}^{+}$cell fraction recapitulated at least the tri-component phenotype of their parental WT. In addition, xenograft tumors initiated from $\mathrm{NCAM}^{+} \mathrm{ALDH} 1^{+}$ cells were further sorted into $\mathrm{NCAM1}^{+} \mathrm{ALDH1} 1^{+}$and $\mathrm{NCAM}^{+}{ }^{+} \mathrm{ALDH} 1^{-}$WT cells and injected into secondary recipients (i.e., NOD-SCID or NOG mice), in serial dilutions. Consequently, only the $\mathrm{NCAM}^{+} \mathrm{ALDH} 1^{+}$samples were capable of tumor initiation. These experiments indicate two fundamental traits exclusively observed in $\mathrm{NCAM}^{+} \mathrm{ALDH} 1^{+}$ cells: in vivo differentiation and self-renewal capacities, implicating this cell fraction as the Wilms' tumor CSCs (Fig. 4). In vitro data corroborated in vivo experiments disclosing "stemness" properties of $\mathrm{NCAM}^{+} \mathrm{ALDH} 1^{+}$WT cells; qRTPCR of $\mathrm{NCAM}^{+} \mathrm{ALDH}^{+}$demonstrated significant elevation of transcripts of renal progenitor genes (i.e., NCAM1, SALL1, SIX2, OSR1), "stemness" genes (i.e., BMI1, EZH2, OCT4) and poor prognostic genes (i.e., TOP $2 A, N-M Y C, C R A B 2 P$ ) in comparison to $\mathrm{NCAM1}^{+} \mathrm{ALDH}^{-}$cells. In addition, colony-forming assays showed a significantly higher number of clones and larger colonies in $\mathrm{NCAM}^{+} \mathrm{ALDH}^{+}$compared to $\mathrm{NCAM}^{+}{ }^{+} \mathrm{ALDH} 1^{-}$cells, in line with their $\mathrm{CSC}$ phenotype [42].

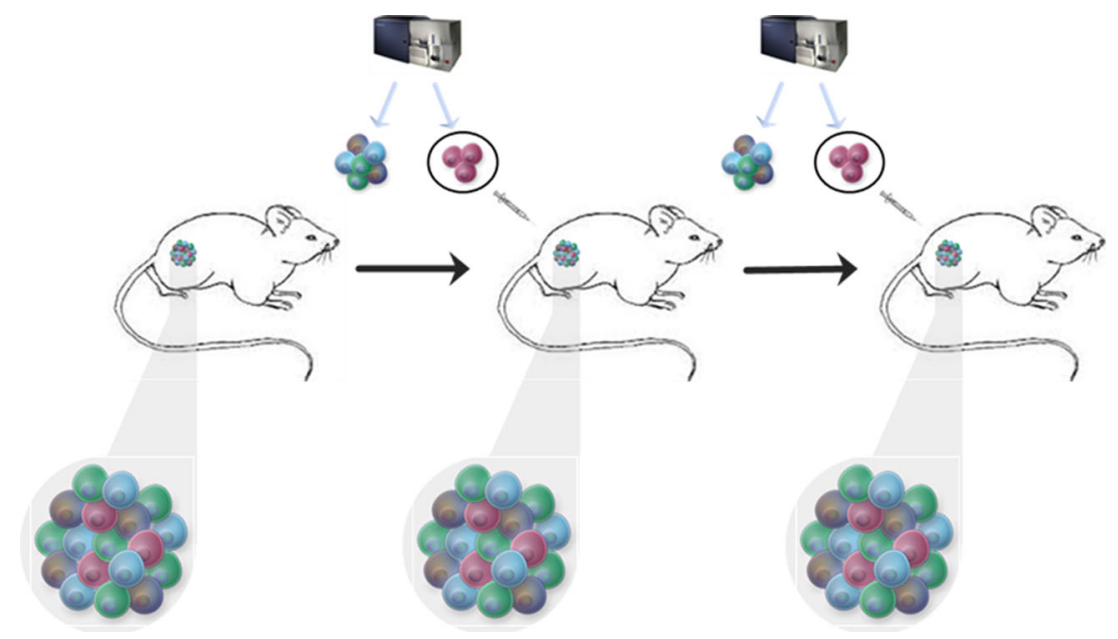

Fig. 4 In vivo self-renewal of WT CSCs. Wilms' tumor xenografts were sorted according to NCAM1 expression and ALDH1 activity in order to isolate the CSCs. Two hundred $\mathrm{NCAM}^{+} \mathrm{ALDH}^{+}$Wilms' tumor xenograft-derived cells were injected into immunodeficient mice and a heterogeneous Wilms' tumor was formed. The tumor was then dissociated into a single cell suspension and the CSCs were again sorted and injected into immunodeficient mice. The procedure was repeated several times, demonstrating the CSCs' in vivo self-renewal capacity 
Hence, the identification and characterization of the WT cancer stem cells unveiled new therapeutic targets in WT.

\section{Wilms' tumor treatment}

Several decades ago, WT was mainly treated by means of nephrectomy and postoperative radiotherapy, with only $30 \%$ surviving their illness [33]. Today, most WT patients are treated with a combination of surgery and chemotherapy, while cases exhibiting poor prognostic factors are treated with radiotherapy. Reports from the National Wilms' Tumor Studies (NWTS) identified lymph node metastases and anaplastic histology as the most significant factors predicting long-term survival [45]. As a result of treatment protocol improvement, the 5-year overall survival for patients with WT is now over $90 \%$ [46]. Despite overall improved outcomes, WT treatment holds two significant challenges: tumor relapse and late adverse effects. According to the International Society of Pediatric Oncology, the relapse rate of patients is $12 \%$, with an overall survival of $48 \%$ in recurrent disease [47]. In patients without metastatic disease at presentation, approximately $75 \%$ of all recurrences occur within 1 year after treatment completion [48]. The prevalence of late adverse effects in long-term WT survivors is high, especially after radiotherapy and treatment with anthracyclines [49]; studies on survivors of childhood cancer have shown that $68 \%$ of WT survivors had developed chronic health problems [50], among the most clinically significant effects are: musculoskeletal abnormalities, cardiac toxicity, reproductive problems, renal dysfunction, and the development of secondary malignant neoplasms [51]. Great efforts are being made to improve the efficiency of WT treatments. Novel targeted treatment strategies are needed to improve clinical outcomes for children with WT as well as to reduce the toxic adverse effects of available treatment options.

\section{Targeted therapy_targeting CSCs in WT}

Anti-tumor targeted therapies are treatments aimed at specific characteristics of cancer cells that are crucial for tumor initiation and maintenance. Due to their specificity, targeted therapies are less likely to harm normal, healthy cells compared to systemic chemotherapy or radiation therapy, and therefore are expected to cause fewer side effects.

Thus far, several targeted treatments, each directed at a specific cancer trait, have been approved for clinical use. A few examples are outlined: (1) targeting of specific cell signaling pathways such as the epidermal growth factor inhibitorscetuximab (Erbitux), a chimeric (mouse/human) monoclonal antibody $(\mathrm{mAb})$, used in the treatment of colorectal cancer and head and neck carcinoma [52-55], trastuzumab (Herceptin), an anti-HER2 mAb, used against breast tumors and metastatic gastric cancer-expressing HER2 [56]; (2) interference with tumor angiogenesis - bevacizumab (Avastin), an anti-VEGFA humanized $\mathrm{mAb}$, used against colorectal, lung, breast, glioblastoma, kidney, and ovarian tumors [57, 58]; (3) targeting of specific tumor antigens-rituximab (MabThera), an antiCD20 mAb, used against non Hodgkin's lymphoma [59]. A growing number of targeted treatments have reached the clinical setting; some replacing the conventional systemic treatments and others are used in conjunction with them to allow application of lower doses of the later, more toxic, drugs.

From a translational aspect, cancer stem cell theory predicts that CSCs should be the preferred targets of anti-cancer treatment, as they are the driving force behind tumor initiation, propagation, and recurrence $[60,61]$. However, their inherent traits, which allow them to escape conventional
Fig. 5 Targeting of WT $\mathrm{NCAM}^{+}$cells in vivo with a humanized NCAM1 antibody drug conjugate (ADC). Targeting the human WT $\mathrm{NCAM}^{+}$cell fraction with an anti-NCAM1 antibody-toxin conjugate (HuN901-DMI) resulted in loss of the WT CSCs, followed by complete tumor degradation

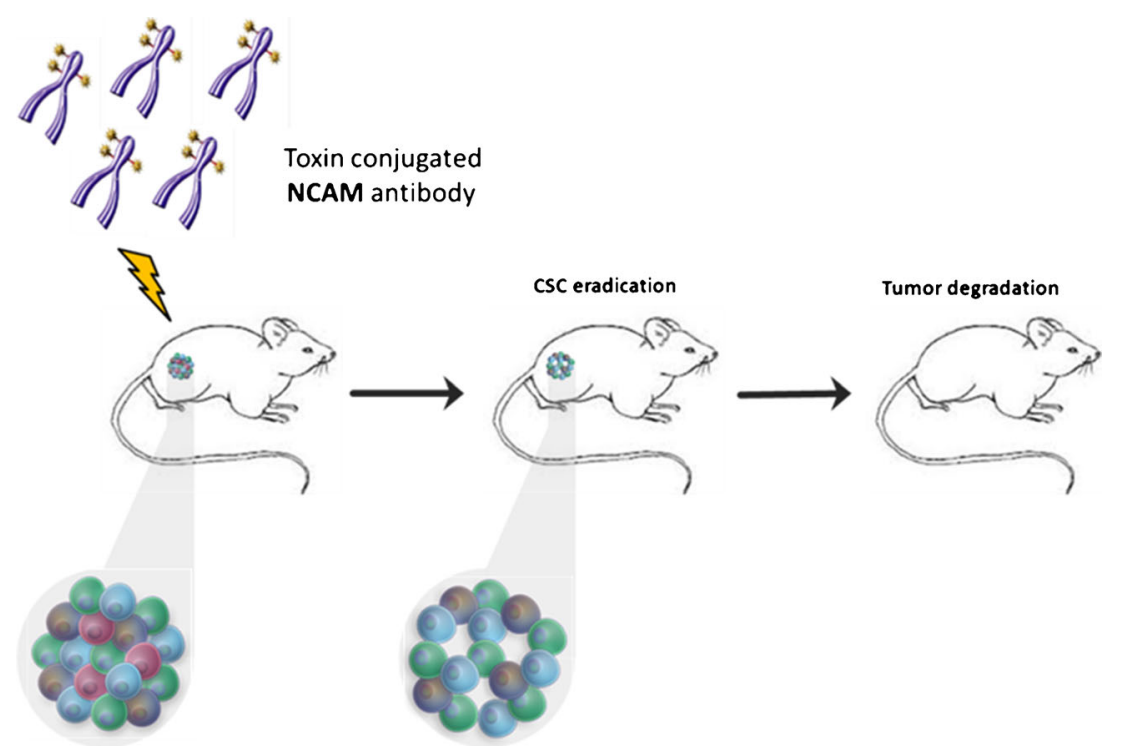


chemo/radiotherapies, necessitate the development of alternative treatment options directed at these highly malignant and therapy-resistant cancer cells. Although therapeutics aimed at CSC eradication have not yet reached clinical use, there are several novel reports of targeted CSC therapy in animal models or in clinical trials $[62,63]$.

Due to tissue availability and a well-characterized cellular hierarchy of the normal hematopoietic system, the most studied CSCs are those of acute myeloid leukemia (AML), isolated over a decade ago [24]. This discovery was followed by several efforts aimed at targeting the hematopoietic cancer stem cell markers, such as CD44 and CD123 in AML [64-68]. Further studies have since been performed by targeting CSCs in several solid tumors such as pancreatic, breast, prostate and colon cancers, melanoma, glioma, hepatocellular carcinoma, and others. These therapies are aimed at targeting a tumor-specific antigen (e.g., CD133, EpCAM, CD24 etc.) [69-71], inhibiting a signaling pathway predominantly activated in the CSCs (e.g., Notch, Wnt etc.) $[72,73]$, immunomodulation (e.g., CD326, ALDH1 inhibitor) [73, 74], sensitizing CSCs to systemic chemotherapy/radiation (e.g., IL4, hyaluronate receptor) $[56,75]$ or inhibiting CSC angiogenesis (e.g., VEGF-R, DLL4) [76-78]. An important contribution of CSC research to anti-cancer targeted treatment is that it unveils specific biomarkers which can be targeted in vivo by antibody therapy leading to disrupted tumor growth $[60,67,79,80]$. Several of these antigens have been known to be expressed in different malignancies, long before their implication as CSC markers. However, their specific targeting was put forward as means to treat human malignancies only following the revelation of their role in signifying the CSC population $[67,81,82]$.

Consequently, we found NCAM1, which has been known to be expressed in WT since the 1980 s, to mark WT CSCs, hence the importance of its targeting.

The importance of targeting the WT CSCs is also supported by our data, showing that first-line chemotherapeutics used to treat WT patients do not have a prominent effect on either the $\mathrm{NCAM}^{+}$or $\mathrm{NCAM}^{+} \mathrm{ALDH}^{+}$cells in vitro. The second-line course of therapy, used to treat WT patients whose disease recurred, reduces these cell populations in vitro, however, clearly does not eradicate all WT CSCs. Currently, chemotherapy regimens used to treat WT patients are employed at doses that lead to numerous adverse effects, perhaps the most feared being devastating secondary malignancies emerging about $20-30$ years following treatment completion [83-86]. Taking into account that WT is usually diagnosed before 5 years of age, these effects possess an even greater impact, taking place in the patient's early adulthood.

We have recently shown that targeting the human $\mathrm{NCAM}^{+}$cell fraction with an anti-NCAM antibody-drug conjugate (ADC) (HuN901-DMI) resulted in loss of the
WT CSCs, both in vitro and in vivo [42]. In vitro, treatment of both primary and xenograft-derived WT cell cultures with the anti-NCAM ADC, resulted in depletion of their "stemness" properties (CFU capacity, proliferation). In vivo, targeting $\mathrm{NCAM}^{+}$WT cells in multiple WT xenograft models with HuN901-DMI showed dramatic results: treatment of mice bearing human WTs with high NCAM expression resulted in complete eradication of the tumors in the majority of cases (Fig. 5) while on solitary occasions, a significant reduction in tumor volume was detected. Treatment of low NCAM-expressing WT xenograft with HuN901-DMI resulted in reduction of tumor size followed by a plateau, suggesting that once all $\mathrm{NCAM}^{+}$cells, which are solely responsible for tumor growth, were eliminated, the remaining $\mathrm{NCAM}^{-}$cells that comprise most of these tumors lacked tumorigenic capacity. The treatment did not cause any toxic effect. Our data suggests that low NCAMexpressing WT xenografts and primary WT possess similar NCAM levels. Thus, we propose that the deployment of the anti-NCAM ADC for eliminating the WT-CSCs, in combination with low-dose conventional chemotherapy for noncancer initiating cancer cells, would show the best efficacy for primary tumor eradications and is more likely to be clinically relevant.

Altogether, NCAM, serving as a definite marker for WT CSCs, can be exploited as a therapeutic target in WT patients. Moreover, although NCAM is a renal developmental marker [87-90], human nephrogenesis completely ceases at 34 weeks of human gestation, excluding the potential for aberrant development caused by anti-NCAM treatment. Therefore, from a clinical standpoint, a combined regimen involving the specific eradication of the WT CICs via targeting of the NCAM molecule, might prove useful in reducing chemotherapy toxicity in all WT patients and particularly in those that do not respond to conventional treatment or those with recurrent disease.

\section{Key summary points}

- Wilms' tumor (WT), the most common pediatric solid tumor of the kidney, is believed to arise from renal precursor cells that have failed to differentiate properly.

- Cancer stem cells (CSCs) are defined by two main properties: self-renewal and differentiation capacities. In recent years the CSC population has been identified in a growing number of solid and hematologic malignancies.

- NCAM1+ALDH1+ cells have been identified as the CSC fraction in WT. The capability of the tumor to grow and propagate is maintained solely by these cells.

- The use of an anti-NCAM1 antibody-drug conjugate (HuN901-DMI) results in loss of the WT CSCs, both in vitro and in vivo, causing tumor size reduction and loss of tumorigenic capacity. 


\section{Multiple choice questions (answers are provided following the reference list)}

1. Which of the following statements regarding Wilms' tumor epidemiology is correct?
a. Most patients have familial history
b. WT is the most frequent pediatric tumor
c. Two thirds of all WT cases cannot be linked to any genetic aberration
d. The tumor is more common among males

2. What is the definition of a cancer stem cell?
a. Activation of pluripotency genes (ie Oct4, Sox2, Nanog)
b. Multi-drug resistance
c. Formation of tumor spheres in low-adherence cultures
d. Self-renewal and differentiation capacities

3. Which of the following assays does not serve as a method for CSC identification and isolation?
a. Doubling time assay
b. Side population assay
c. Label retention cell assay
d. Colony formation assay

4. What is the common practice for WT patients?
a. Nephrectomy and postoperative radiotherapy
b. Targeted therapy aimed at cancer stem cells
c. A combination of surgery and chemotherapy
d. Conservative treatment based on low protein diet

5. Choose the incorrect sentence regarding the results of an anti-NCAM1 antibody-drug conjugate (HuN901-DMI)?

a. In vitro, the treatment resulted in depletion of the cell's 'stemness' properties (CFU capacity, proliferation)

b. HuN901-DMI treatment presented a toxic effect, represented by mice weight loss

c. Treatment of mice bearing human WTs with high NCAM1 expression resulted in complete eradication of the tumors in the majority of cases

d. Treatment of low NCAM1 expressing WT xenograft resulted in reduction of tumor size followed by a plateau

\section{References}

1. Beckwith JB (1983) Wilms' tumor and other renal tumors of childhood: a selective review from the National Wilms' Tumor Study Pathology Center. Hum Pathol 14:481-492

2. Matsunaga E (1981) Genetics of Wilms' tumor. Hum Genet $57: 231-246$
3. Huff V (2011) Wilms' tumours: about tumour suppressor genes, an oncogene and a chameleon gene. Nat Rev Cancer 11:111-121

4. Li CM, Guo M, Borczuk A, Powell CA, Wei M, Thaker HM, Friedman R, Klein U, Tycko B (2002) Gene expression in Wilms' tumor mimics the earliest committed stage in the metanephric mesenchymal-epithelial transition. Am J Pathol 160:2181-2190

5. Dekel B, Metsuyanim S, Schmidt-Ott KM, Fridman E, JacobHirsch J, Simon A, Pinthus J, Mor Y, Barasch J, Amariglio N, Reisner Y, Kaminski N, Rechavi G (2006) Multiple imprinted and stemness genes provide a link between normal and tumor progenitor cells of the developing human kidney. Cancer Res 66:6040 6049

6. Metsuyanim S, Pode-Shakked N, Schmidt-Ott KM, Keshet G, Rechavi G, Blumental D, Dekel B (2008) Accumulation of malignant renal stem cells is associated with epigenetic changes in normal renal progenitor genes. Stem Cells 26:1808-1817

7. Aiden AP, Rivera MN, Rheinbay E, Ku M, Coffman EJ, Truong TT, Vargas SO, Lander ES, Haber DA, Bernstein BE (2010) Wilms' tumor chromatin profiles highlight stem cell properties and a renal developmental network. Cell Stem Cell 6:591-602

8. Feinberg AP, Williams BR (2003) Wilms' tumor as a model for cancer biology. Methods Mol Biol 222:239-248

9. Bolande RP, Vekemans MJ (1983) Genetic models of carcinogenesis. Hum Pathol 14:658-662

10. Pode-Shakked N, Dekel B (2011) Wilms' tumor-a renal stem cell malignancy? Pediatr Nephrol 26:1535-1543

11. Hope KJ, Jin L, Dick JE (2004) Acute myeloid leukemia originates from a hierarchy of leukemic stem cell classes that differ in selfrenewal capacity. Nat Immunol 5:738-743

12. Lobo NA, Shimono Y, Qian D, Clarke MF (2007) The biology of cancer stem cells. Annu Rev Cell Dev Biol 23:675-699

13. Hanahan D, Weinberg RA (2000) The hallmarks of cancer. Cell 100:57-70

14. Spradling A, Drummond-Barbosa D, Kai T (2001) Stem cells find their niche. Nature 414:98-104

15. Zhang J, Niu C, Ye L, Huang H, He X, Tong WG, Ross J, Haug J, Johnson T, Feng JQ, Harris S, Wiedemann LM, Mishina Y, Li L (2003) Identification of the haematopoietic stem cell niche and control of the niche size. Nature 425:836-841

16. Jackson EB, Breus AM (1941) Studies on a transplantable embryoma of the mouse. Cancer Res 1:494-498

17. Bruce WR, Van Der Gaag H (1963) A quantitative assay for the number of murine lymphoma cells capable of proliferation in vivo. Nature 199:79-80

18. Hamburger A, Salmon SE (1977) Primary bioassay of human myeloma stem cells. J Clin Invest 60:846-854

19. Hamburger AW, Salmon SE (1977) Primary bioassay of human tumor stem cells. Science 197:461-463

20. Buick RN, Stanisic TH, Fry SE, Salmon SE, Trent JM, Krasovich P (1979) Development of an agar-methyl cellulose clonogenic assay for cells in transitional cell carcinoma of the human bladder. Cancer Res 39:5051-5056

21. Salmon SE, Buick RN (1979) Preparation of permanent slides of intact soft-agar colony cultures of hematopoietic and tumor stem cells. Cancer Res 39:1133-1136

22. McCulloch EA, Howatson AF, Buick RN, Minden MD, Izaguirre CA (1979) Acute myeloblastic leukemia considered as a clonal hemopathy. Blood Cells 5:261-282

23. Buick RN, Minden MD, McCulloch EA (1979) Self-renewal in culture of proliferative blast progenitor cells in acute myeloblastic leukemia. Blood 54:95-104

24. Bonnet D, Dick JE (1997) Human acute myeloid leukemia is organized as a hierarchy that originates from a primitive hematopoietic cell. Nat Med 3:730-737

25. Lapidot T, Sirard C, Vormoor J, Murdoch B, Hoang T, CaceresCortes J, Minden M, Paterson B, Caligiuri MA, Dick JE (1994) A 
cell initiating human acute myeloid leukaemia after transplantation into SCID mice. Nature 367:645-648

26. Al-Hajj M, Wicha MS, Benito-Hernandez A, Morrison SJ, Clarke MF (2003) Prospective identification of tumorigenic breast cancer cells. Proc Natl Acad Sci U S A 100:3983-3988

27. Singh SK, Hawkins C, Clarke ID, Squire JA, Bayani J, Hide T, Henkelman RM, Cusimano MD, Dirks PB (2004) Identification of human brain tumour-initiating cells. Nature 432:396-401

28. O'Brien CA, Pollett A, Gallinger S, Dick JE (2007) A human colon cancer cell capable of initiating tumour growth in immunodeficient mice. Nature 445:106-110

29. Chen YC, Chen YW, Hsu HS, Tseng LM, Huang PI, Lu KH, Chen DT, Tai LK, Yung MC, Chang SC, Ku HH, Chiou SH, Lo WL (2009) Aldehyde dehydrogenase 1 is a putative marker for cancer stem cells in head and neck squamous cancer. Biochem Biophys Res Commun 385:307-313

30. Dylla SJ, Beviglia L, Park IK, Chartier C, Raval J, Ngan L, Pickell K, Aguilar J, Lazetic S, Smith-Berdan S, Clarke MF, Hoey T, Lewicki J, Gurney AL (2008) Colorectal cancer stem cells are enriched in xenogeneic tumors following chemotherapy. PLoS One 3:e2428

31. Tanei T, Morimoto K, Shimazu K, Kim SJ, Tanji Y, Taguchi T, Tamaki Y, Noguchi S (2009) Association of breast cancer stem cells identified by aldehyde dehydrogenase 1 expression with resistance to sequential Paclitaxel and epirubicin-based chemotherapy for breast cancers. Clin Cancer Res 15:4234-4241

32. Chuthapisith S, Eremin J, El-Sheemey M, Eremin O (2009) Breast cancer chemoresistance: emerging importance of cancer stem cells. Surg Oncol 19:27-32

33. Ginestier C, Hur MH, Charafe-Jauffret E, Monville F, Dutcher J, Brown M, Jacquemier J, Viens P, Kleer CG, Liu S, Schott A, Hayes D, Birnbaum D, Wicha MS, Dontu G (2007) ALDH1 is a marker of normal and malignant human mammary stem cells and a predictor of poor clinical outcome. Cell Stem Cell 1:555-567

34. Ma S, Chan KW, Lee TK, Tang KH, Wo JY, Zheng BJ, Guan XY (2008) Aldehyde dehydrogenase discriminates the CD133 liver cancer stem cell populations. Mol Cancer Res 6:1146-1153

35. Pearce DJ, Taussig D, Simpson C, Allen K, Rohatiner AZ, Lister TA, Bonnet D (2005) Characterization of cells with a high aldehyde dehydrogenase activity from cord blood and acute myeloid leukemia samples. Stem Cells 23:752-760

36. Li C, Heidt DG, Dalerba P, Burant CF, Zhang L, Adsay V, Wicha M, Clarke MF, Simeone DM (2007) Identification of pancreatic cancer stem cells. Cancer Res 67:1030-1037

37. Prince ME, Sivanandan R, Kaczorowski A, Wolf GT, Kaplan MJ, Dalerba P, Weissman IL, Clarke MF, Ailles LE (2007) Identification of a subpopulation of cells with cancer stem cell properties in head and neck squamous cell carcinoma. Proc Natl Acad Sci U S A 104:973-978

38. Collins AT, Berry PA, Hyde C, Stower MJ, Maitland NJ (2005) Prospective identification of tumorigenic prostate cancer stem cells. Cancer Res 65:10946-10951

39. Tang C, Ang BT, Pervaiz S (2007) Cancer stem cell: target for anticancer therapy. FASEB J 21:3777-3785

40. Gerber JM, Smith BD, Ngwang B, Zhang H, Vala MS, Morsberger L, Galkin S, Collector MI, Perkins B, Levis MJ, Griffin CA, Sharkis SJ, Borowitz MJ, Karp JE, Jones RJ (2012) A clinically relevant population of leukemic CD34(+)CD38(-) cells in acute myeloid leukemia. Blood 119:3571-3577

41. Alison MR, Lim SM, Nicholson LJ (2011) Cancer stem cells: problems for therapy? J Pathol 223:147-161

42. Pode-Shakked N, Shukrun R, Mark-Danieli M, Tsvetkov P, Bahar S, Pri-Chen S, Goldstein RS, Rom-Gross E, Mor Y, Fridman E, Meir K, Simon A, Magister M, Kaminski N, Goldmacher VS, Harari-Steinberg O, Dekel B (2013) The isolation and characterization of renal cancer initiating cells from human Wilms' tumour xenografts unveils new therapeutic targets. EMBO Mol Med 5:18-37

43. Wen JG, van Steenbrugge GJ, Egeler RM, Nijman RM (1997) Progress of fundamental research in Wilms' tumor. Urol Res 25:223-230

44. Pode-Shakked N, Metsuyanim S, Rom-Gross E, Mor Y, Fridman E, Goldstein I, Amariglio N, Rechavi G, Keshet G, Dekel B (2009) Developmental tumourigenesis: NCAM1 as a putative marker for the malignant renal stem/progenitor cell population. J Cell Mol Med 13:1792-1808

45. Breslow N, Sharples K, Beckwith JB, Takashima J, Kelalis PP, Green DM, D'Angio GJ (1991) Prognostic factors in nonmetastatic, favorable histology Wilms' tumor. Results of the Third National Wilms' Tumor Study. Cancer 68:2345-2353

46. Smith MA, Seibel NL, Altekruse SF, Ries LA, Melbert DL, O'Leary M, Smith FO, Reaman GH (2010) Outcomes for children and adolescents with cancer: challenges for the twenty-first century. J Clin Oncol 28:2625-2634

47. Davos I, Abell MR (1976) Soft tissue sarcomas of vulva. Gynecol Oncol 4:70-86

48. Sutow WW, Breslow NE, Palmer NF, D'Angio GJ, Takashima J (1982) Prognosis in children with Wilms' tumor metastases prior to or following primary treatment: results from the first National Wilms' Tumor Study (NWTS-1). Am J Clin Oncol 5:339-347

49. van Dijk IW, Oldenburger F, Cardous-Ubbink MC, Geenen MM, Heinen RC, de Kraker J, van Leeuwen FE, van der Pal HJ, Caron HN, Koning CC, Kremer LC (2010) Evaluation of late adverse events in long-term Wilms' tumor survivors. Int J Radiat Oncol Biol Phys 78:370-378

50. Curry HL, Parkes SE, Powell JE, Mann JR (2006) Caring for survivors of childhood cancers: the size of the problem. Eur $\mathrm{J}$ Cancer 42:501-508

51. Wright KD, Green DM, Daw NC (2009) Late effects of treatment for Wilms' tumor. Pediatr Hematol Oncol 26:407-413

52. (2006) Cetuximab approved by FDA for treatment of head and neck squamous cell cancer. Cancer Biol Ther 5:340-342

53. Astsaturov I, Cohen RB, Harari P (2007) EGFR-targeting monoclonal antibodies in head and neck cancer. Curr Cancer Drug Targets 7:650-665

54. Gatto B (2004) Monoclonal antibodies in cancer therapy. Curr Med Chem Anticancer Agents 4:411-414

55. Reid A, Vidal L, Shaw H, de Bono J (2007) Dual inhibition of ErbB1 (EGFR/HER1) and ErbB2 (HER2/neu). Eur J Cancer 43:481-489

56. Todaro M, Alea MP, Di Stefano AB, Cammareri P, Vermeulen L, Iovino F, Tripodo C, Russo A, Gulotta G, Medema JP, Stassi G (2007) Colon cancer stem cells dictate tumor growth and resist cell death by production of interleukin-4. Cell Stem Cell 1:389-402

57. Cohen MH, Gootenberg J, Keegan P, Pazdur R (2007) FDA drug approval summary: bevacizumab (Avastin) plus Carboplatin and Paclitaxel as first-line treatment of advanced/metastatic recurrent nonsquamous non-small cell lung cancer. Oncologist 12:713-718

58. Cohen MH, Gootenberg J, Keegan P, Pazdur R (2007) FDA drug approval summary: bevacizumab plus FOLFOX4 as second-line treatment of colorectal cancer. Oncologist 12:356-361

59. Coiffier B (2007) Rituximab therapy in malignant lymphoma. Oncogene 26:3603-3613

60. Clarke MF, Dick JE, Dirks PB, Eaves CJ, Jamieson CH, Jones DL, Visvader J, Weissman IL, Wahl GM (2006) Cancer stem cellsperspectives on current status and future directions: AACR Workshop on cancer stem cells. Cancer Res 66:9339-9344

61. Reya T, Morrison SJ, Clarke MF, Weissman IL (2001) Stem cells, cancer, and cancer stem cells. Nature 414:105-111

62. Pode Shakked N, Harari-Steinberg O, Haberman Y, Rom-Gross E, Zangi L, Bahar S, Omer D, Metsuyanim S, Buzhor E, Ronald S Goldstein, Michal Mark-Danieli, Dekel B (2011) Resistance or 
sensitivity of Wilms' tumor to anti-FZD7 antibody highlights the Wnt pathway as a possible therapeutic target. Oncogene 30:1664-80

63. Deonarain MP, Kousparou CA, Epenetos AA (2009) Antibodies targeting cancer stem cells: a new paradigm in immunotherapy? MAbs 1:12-25

64. McWhirter JR, Kretz-Rommel A, Saven A, Maruyama T, Potter KN, Mockridge CI, Ravey EP, Qin F, Bowdish KS (2006) Antibodies selected from combinatorial libraries block a tumor antigen that plays a key role in immunomodulation. Proc Natl Acad Sci U S A 103:1041-1046

65. Stein C, Kellner C, Kugler M, Reiff N, Mentz K, Schwenkert M, Stockmeyer B, Mackensen A, Fey GH (2010) Novel conjugates of single-chain $\mathrm{Fv}$ antibody fragments specific for stem cell antigen CD123 mediate potent death of acute myeloid leukaemia cells. Br J Haematol 148:879-889

66. Du X, Ho M, Pastan I (2007) New immunotoxins targeting CD123, a stem cell antigen on acute myeloid leukemia cells. J Immunother 30:607-613

67. Jin L, Hope KJ, Zhai Q, Smadja-Joffe F, Dick JE (2006) Targeting of CD44 eradicates human acute myeloid leukemic stem cells. Nat Med 12:1167-1174

68. Jin L, Lee EM, Ramshaw HS, Busfield SJ, Peoppl AG, Wilkinson L, Guthridge MA, Thomas D, Barry EF, Boyd A, Gearing DP, Vairo G, Lopez AF, Dick JE, Lock RB (2009) Monoclonal antibody-mediated targeting of CD123, IL-3 receptor alpha chain, eliminates human acute myeloid leukemic stem cells. Cell Stem Cell 5:31-42

69. Goel S, Bauer RJ, Desai K, Bulgaru A, Iqbal T, Strachan BK, Kim G, Kaubisch A, Vanhove GF, Goldberg G, Mani S (2007) Pharmacokinetic and safety study of subcutaneously administered weekly ING-1, a human engineered monoclonal antibody targeting human EpCAM, in patients with advanced solid tumors. Ann Oncol 18:1704-1707

70. Smith LM, Nesterova A, Ryan MC, Duniho S, Jonas M, Anderson M, Zabinski RF, Sutherland MK, Gerber HP, Van Orden KL, Moore PA, Ruben SM, Carter PJ (2008) CD133/prominin-1 is a potential therapeutic target for antibody-drug conjugates in hepatocellular and gastric cancers. Br J Cancer 99:100-109

71. Sagiv E, Starr A, Rozovski U, Khosravi R, Altevogt P, Wang T, Arber N (2008) Targeting CD24 for treatment of colorectal and pancreatic cancer by monoclonal antibodies or small interfering RNA. Cancer Res 68:2803-2812

72. Rizzo P, Osipo C, Foreman K, Golde T, Osborne B, Miele L (2008) Rational targeting of Notch signaling in cancer. Oncogene 27:5124-5131

73. He B, You L, Uematsu K, Xu Z, Lee AY, Matsangou M, McCormick F, Jablons DM (2004) A monoclonal antibody against Wnt-1 induces apoptosis in human cancer cells. Neoplasia 6:7-14

74. Naundorf S, Preithner S, Mayer P, Lippold S, Wolf A, Hanakam F, Fichtner I, Kufer P, Raum T, Riethmuller G, Baeuerle PA, Dreier T (2002) In vitro and in vivo activity of MT201, a fully human monoclonal antibody for pancarcinoma treatment. Int J Cancer 100:101-110

75. Colnot DR, Roos JC, de Bree R, Wilhelm AJ, Kummer JA, Hanft G, Heider KH, Stehle G, Snow GB, van Dongen GA (2003) Safety, biodistribution, pharmacokinetics, and immunogenicity of 99mTc-labeled humanized monoclonal antibody BIWA 4 (bivatuzumab) in patients with squamous cell carcinoma of the head and neck. Cancer Immunol Immunother 52:576-582

76. Ridgway J, Zhang G, Wu Y, Stawicki S, Liang WC, Chanthery Y, Kowalski J, Watts RJ, Callahan C, Kasman I, Singh M, Chien M,
Tan C, Hongo JA, de Sauvage F, Plowman G, Yan M (2006) Inhibition of Dll4 signalling inhibits tumour growth by deregulating angiogenesis. Nature 444:1083-1087

77. Folkins C, Man S, Xu P, Shaked Y, Hicklin DJ, Kerbel RS (2007) Anticancer therapies combining antiangiogenic and tumor cell cytotoxic effects reduce the tumor stem-like cell fraction in glioma xenograft tumors. Cancer Res 67:3560-3564

78. Jain RK (2008) Lessons from multidisciplinary translational trials on anti-angiogenic therapy of cancer. Nat Rev Cancer 8:309-316

79. Galmozzi E, Facchetti F, La Porta CA (2006) Cancer stem cells and therapeutic perspectives. Curr Med Chem 13:603-607

80. Huntly BJ, Gilliland DG (2005) Leukaemia stem cells and the evolution of cancer-stem-cell research. Nat Rev Cancer 5:311-321

81. Naor D, Nedvetzki S, Golan I, Melnik L, Faitelson Y (2002) CD44 in cancer. Crit Rev Clin Lab Sci 39:527-579

82. Naor D, Sionov RV, Ish-Shalom D (1997) CD44: structure, function, and association with the malignant process. Adv Cancer Res 71:241-319

83. Robison LL (2005) The Childhood Cancer Survivor Study: a resource for research of long-term outcomes among adult survivors of childhood cancer. Minn Med 88:45-49

84. Geenen MM, Cardous-Ubbink MC, Kremer LC, van den Bos C, van der Pal HJ, Heinen RC, Jaspers MW, Koning CC, Oldenburger F, Langeveld NE, Hart AA, Bakker PJ, Caron HN, van Leeuwen FE (2007) Medical assessment of adverse health outcomes in longterm survivors of childhood cancer. JAMA 297:2705-2715

85. Moss TJ, Strauss LC, Das L, Feig SA (1989) Secondary leukemia following successful treatment of Wilms' tumor. Am J Pediatr Hematol Oncol 11:158-161

86. Vane D, King DR, Boles ET Jr (1984) Secondary thyroid neoplasms in pediatric cancer patients: increased risk with improved survival. J Pediatr Surg 19:855-860

87. Roth J, Zuber C, Wagner P, Blaha I, Bitter-Suermann D, Heitz PU (1988) Presence of the long chain form of polysialic acid of the neural cell adhesion molecule in Wilms' tumor. Identification of a cell adhesion molecule as an oncodevelopmental antigen and implications for tumor histogenesis. Am J Pathol 133:227-240

88. Metsuyanim S, Harari-Steinberg O, Buzhor E, Omer D, PodeShakked N, Ben-Hur H, Halperin R, Schneider D, Dekel B (2009) Expression of stem cell markers in the human fetal kidney. PLoS One 4:e6709

89. Evseenko D, Zhu Y, Schenke-Layland K, Kuo J, Latour B, Ge S, Scholes J, Dravid G, Li X, MacLellan WR, Crooks GM (2010) Mapping the first stages of mesoderm commitment during differentiation of human embryonic stem cells. Proc Natl Acad Sci U S A 107:13742-13747

90. Bard JB, Gordon A, Sharp L, Sellers WI (2001) Early nephron formation in the developing mouse kidney. J Anat 199:385-392

\section{Multiple-choice questions_-answers}
$1-\mathrm{C}$
$2-\mathrm{D}$
$3-\mathrm{A}$
$4-\mathrm{C}$
$5-\mathrm{B}$ 